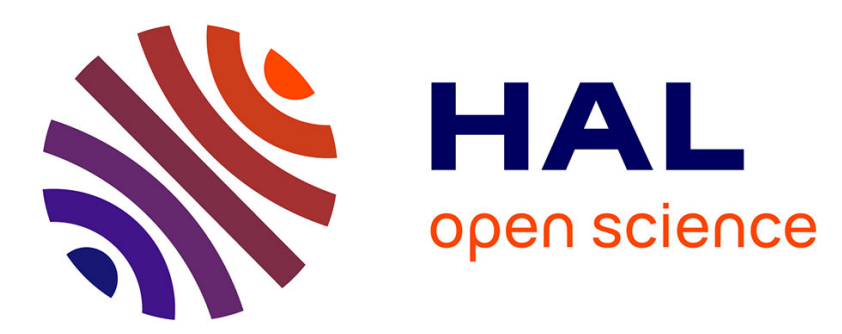

\title{
Framing 'Islamic Art' for aesthetic interiors: revisiting the 1878 Paris exhibition
}

\author{
Moya Carey, Mercedes Volait
}

\section{To cite this version:}

Moya Carey, Mercedes Volait. Framing 'Islamic Art' for aesthetic interiors: revisiting the 1878 Paris exhibition. International Journal of Islamic architecture, inPress. halshs-01867966

\section{HAL Id: halshs-01867966 \\ https://shs.hal.science/halshs-01867966}

Submitted on 4 Sep 2018

HAL is a multi-disciplinary open access archive for the deposit and dissemination of scientific research documents, whether they are published or not. The documents may come from teaching and research institutions in France or abroad, or from public or private research centers.
L'archive ouverte pluridisciplinaire $\mathbf{H A L}$, est destinée au dépôt et à la diffusion de documents scientifiques de niveau recherche, publiés ou non, émanant des établissements d'enseignement et de recherche français ou étrangers, des laboratoires publics ou privés. 


\section{Framing 'Islamic Art' for aesthetic interiors: revisiting the 1878 Paris exhibition}

Moya Carey and Mercedes Volait

The 1878 Exposition Universelle in Paris ran from May 1 to October 31, 1878, and was dedicated to the universal history of labour. This overarching theme included technical skills of fine craftsmanship as well as modern mechanical industry: the resulting displays were very diverse. The international representation was also disparate, reflecting the geopolitical situation of the era, and the specific perspective of France's Third Republic with its colonies, rivals, allies and interests. Within this framework, the exhibition featured a substantial scope of art and architecture from the Middle East ${ }^{1}$ and North Africa: Khedival Egypt, Qajar Iran, Frenchcontrolled Algeria, and the kingdoms of Morocco and Tunisia. This was the most extensive such a range to be offered to an international audience at that time, within the contemporary sequence of international exhibitions spanning from London in 1851, to Vienna in 1873 and Philadelphia in 1876. This article will discuss a series of distinct installations distributed across a complex site which spanned the river Seine, for the 1878 Paris event (Frezouls 1878). ${ }^{2}$ All are related to the visual culture of the Arab, Turkish and Iranian worlds, from the advent of Islam up to modern times. In other words, they fall under the conventional rubric of 'Islamic Art', whatever the acknowledged shortcomings of this art-historiographical term. As will be discussed below, the various presentations followed different formats. Modern manufactured goods were in exhibition halls for commercial sale, temporary outdoor structures exhibited distinctive 'national' architectural modes, and interior galleries showed more highly-regarded historical objects on loan from private art collectors (or amateurs). Iran, Egypt, Tunisia and Morocco participated as nations, while Algeria was presented as a colonial possession of France. The British representation included a substantial display for India, which nonetheless (for reasons to be discussed below) included material from Iran, as well as Afghanistan and Central Asia. Ottoman Turkey did not participate, nor did recently-unified Germany: geopolitical realities could not guarantee a wholly international presence, only seven years after the devastating Franco-Prussian war, and months after the Russo-Turkish conflict. National governments overlapped with commercial firms throughout, and indeed the programme's successful delivery relied upon the deft coordination of diplomatic courtesy and private enterprise. Thus some displays were commercial initiatives under national auspices, such as 'L'Égypte des khalifes', a gallery nominally sponsored (or rather authorised) by the Khedive of Egypt, Isma 'il Pasha (r.1863-79). The purpose-built 'Pavillon de la Perse' was constructed by master-builders dispatched from Qajar Iran, while a separate display of Iran's contemporary manufactures (within the main exhibition building) was coordinated under direct orders from Nasir al-Din Shah (r.1848-96). Ever-present too were commercial undertakings, with retailers offering modern imports, at nationally-allocated stalls within the vast Palais du Champ de Mars, and outdoors in the Trocadéro park. Finally, one further enterprise was the 'Galerie orientale' (or 'Salle orientale'), a loan exhibition curated by the Paris art-dealer Albert Goupil (1840-1884) inside the Palais du Trocadéro, where significant historical pieces in French private collections were on view. These were chiefly from Safavid Iran and Mamluk Egypt and Syria. Goupil and others were in the process of developing an increasingly public scholarly discourse about these objects, coupling academic research with aesthetic collecting, which made the displayed artefacts all the more significant on the art market. 
While the display of Islamic art at national and international exhibitions has received increased attention and research, ${ }^{3}$ comparatively little is known about the artefacts displayed at this specific Paris event, aside from a few celebrated examples. ${ }^{4}$ To date, scholarly literature on the inclusion of Middle Eastern nations at international exhibitions has chiefly addressed Paris $1867^{5}$ and Chicago $1893 ;{ }^{6}$ furthermore, these installations have been analysed mostly through the prism of the 'architecture of Islam', and the national pavilions, which omits those artefacts presented within commercial contexts.

The purpose of this article is to analyse these installations at the 1878 Paris exhibition, by interpreting a wide range of primary sources, and by considering the contemporary context of wider collecting practices, in both Paris and Cairo. It aims to highlight in particular the architectural dimension which would characterise art collecting in the late nineteenth century: diverse fittings, furnishings and salvaged fragments were reformulated as private interior space, and typically the resulting visually-eclectic 'themed rooms' consolidated a social identity for collector networks. In Paris, the central influencers were individuals who had already coordinated such installations while living well in Cairo: Gaston de Saint-Maurice (1831-1905), Alphonse Delort de Gléon (1843-1899) and architect Ambroise Baudry (1838-1906) had held court appointments serving the Khedive of Egypt. All three had built remarkable private houses in Cairo, hôtels particuliers fitted with architectural fragments, plaster casts from historic architecture and modern reformulations of Mamluk woodwork. This fit an existing vogue for selective architectural historicism within cosmopolitan Egyptian society, such as the Alhambrastyle pavilion at Gezira Palace, built by Khedive Isma il to mark the opening of the Suez Canal. ${ }^{7}$ With the fall of the Khedive (under British financial pressure), these individuals would return to France, bringing extensive house collections back with them. ${ }^{8}$ Already developing in Paris, was a different group for whom Middle Eastern art collecting, as displayed in immersive settings in their homes, also evidenced foreign travel, and furthermore denoted intellectual integrity. A pivotal figure was Charles Schéfer (1820-1898), a scholar and linguist, who had collected manuscripts and art objects throughout his diplomatic career in Beirut, Alexandra, Izmir and Damascus, and now taught in Paris. Within a small friendship network crucially linking Schéfer at the École des langues orientales vivantes (est. 1795) and the art journal Gazette des Beaux-Arts (est. 1859), there had begun the gradual publication of illustrated academic research on Middle Eastern visual culture, drawing primarily on Paris-based collections. This was the elite circle whose private loans filled the 1878 Galerie Orientale with Safavid carpets, Mamluk mosque lamps, Indian armour, Spanish ivory and other valuable examples, displayed together with Cairo artefacts supplied by Delort de Gléon. Critically, these diverse artworks were architecturally contained and controlled, reduced to aspects of a private domestic salon, of exclusive access. All of these social and intellectual resonances would soon be carefully exploited on the market, most notably by the art firm Goupil et Cie.

The Paris exhibition in 1878 therefore included two particularly influential and timely displays, of Islamic art objects that were presently to be made available for purchase: from Egypt's national display, Gaston de Saint-Maurice's remarkable fittings and house-contents assembled in Cairo, and the separate Galerie Orientale of artworks from multiple private lenders in Paris. Shortly afterwards, both installations would influence the acquisition and display policies of two European design museums: ${ }^{9}$ the South Kensington Museum (today the V\&A) in London, and the Musée des Arts Décoratifs in Paris. Several South Kensington curators attended the 1878 Paris exhibition: susceptible to elitist nuances, they would retrospectively seek to acquire much of the Middle Eastern material then on display, including the house collection of Gaston de Saint- 
Maurice (purchased in 1884). This energy transformed the Middle Eastern holdings at South Kensington, but pertinently also the manner in which the collections were exhibited: from 1880, South Kensington began to turn towards reconstructions of intimate domestic interiors, such as 'Damascus Rooms'. ${ }^{10}$ With Goupil in Paris, exceptional examples of early Safavid carpets had been wall-mounted: national design museums now began to treat this textile category with a similar aesthetic status to fine art paintings, encouraging direct examination of their designs. Albert Goupil himself would be more directly involved with the Société du musée des arts décoratifs in Paris, becoming its director in 1880, and establishing an 'oriental' department in 1882: at this date, the Société amalgamated with the Union centrale des beaux-arts appliqués à I'industrie, and became the Musée des Arts décoratifs. He also gifted a Safavid silk carpet to the National Manufactory of the Gobelins, as a model pattern for weavers. Following a similar trajectory, South Kensington Museum authorities also acknowledged the likely reference value of Safavid carpet designs for British textile industries, issuing (from 1884) affordable colourprinted Art Portfolio template series, and beginning to purchase historical Iranian carpets. In this sense, it is proposed that in 1878 these various Paris displays demonstrated shifting issues of social and institutional practices, as well as recording certain Middle Eastern design histories.

\section{The Rue des Nations Étrangères and the Palais du Champ de Mars}

Many of the manufactured goods imported from North Africa and the Middle East were located off the 'Rue des nations étrangères' (Street of Foreign Nations). Laid out as an artificial street under the glass roof of the gigantic Palais du Champ de Mars, this avenue ran north to south alongside the central Gallery of Fine Arts. Four house-fronts representing Morocco, Iran, Tunisia and Thailand ('Siam') packed into the tight $10 \mathrm{~m}$-long façade that was allocated to them at the far end of the street; examples of their contemporary manufactures were exhibited in the stands behind.

Less expectedly, objects from the Middle East could also be found within Britain's India section ('Exposition des Indes'). Placed in a prominent position within the 'grand vestibule' of the main exhibition hall, the Indian Court was an intricate wooden structure, painted red with copperplated domes at either end [Figure 1]. This was not architectural salvage from India, but the design of Caspar Purdon Clarke (1846-1911), a South Kensington-trained architect who was also Official Commercial Agent for this section. The President of Britain's organizing Commission for the Paris Exhibition was the Prince of Wales (Queen Victoria's son Albert Edward, later Edward VII). In 1875-6, he had toured India's royal courts, returning with an extensive collection of diplomatic gifts - which were now sent to the Paris exhibition.

Together with this royal loan, British commercial firms were strongly represented in the Indian section: one press reviewer equally admired the 'ravishing' textiles presented by the maharaja of Kashmir, and the 'superb' carpets offered by London-based Vincent J. Robinson (1829-1910) (and two other importers), all apparently viewed together inside the pavilion. ${ }^{11}$ Also described as a 'temple', the pavilion seems to have been reserved for displaying textiles only. ${ }^{12}$ [Figure 2]. 'Persian and Turcoman' carpets were particularly admired, 'for their great excellence of quality and design'. ${ }^{13}$ For example, Robinson displayed three striking carpets now attributed to c.1600 Safavid Isfahan, but then often termed Afghan or Herati: 'The Afghanistan carpet exhibited by Messrs. Vincent Robinson \& Co. is probably really of Mashhad manufacture. It is a rare example of the antique Persian style in carpets' ${ }^{14}$ This praise fits a broader critical enthusiasm for the historical Iranian carpets on display elsewhere in the Paris exhibition. Arguably Birdwood's warm 
words were linked with the conducive architectural surroundings in which they were encountered in Paris: the arcaded interior of the Indian-style pavilion created an intimate aesthetic context, within which visitors now felt encouraged to look more closely and appreciatively at the beautiful objects before them. Was an architectural presentation affecting viewers, in response to these impressive and relatively private spaces? ${ }^{15}$

\section{The Trocadéro Park: Tunisia, Morocco, Iran, Algeria and Egypt}

The British Indian pavilion was unusual in that it was indoors, within the vestibule of the main exhibition hall. Outdoors, the architecture of Middle East and North Africa was prominent in the Trocadéro park across the river. A series of national pavilions was built around these gardens, tellingly dwarfed by the immense modern structures to either side. ${ }^{16}$ This was a diverse and rather uneven group, with different facilities offered within temporary structures, built to demonstrate the typical architectural idiom of each country. Press commentary confirms that these displays were enjoyed as exoticized amenities for shopping and leisure, and also treated with curiosity. The Tunisian pavilion hosted a popular music café and three commercial exhibitors, one being the 'bazaar' of Abdallah ben Athia, selling examples of modern Tunisian craftsmanship, including textiles, leatherwork and mother-of-pearl-inlaid furniture. The Pavilion of Morocco was an example of a typical house, modelled on a grand example in Tangiers. Three shops were attached to it, where visitors could watch filigree jewellery being handmade, taste hashish or sip local liqueurs. ${ }^{17}$

The Persian Pavilion was modelled upon the newly-built (1874-75) Eshratabad royal palace in Qajar Tehran, as Nasir al-Din Shah exclaimed on visiting. ${ }^{18}$ One upper room was minutely vaulted with mirror-mosaic, or aineh-kari, a fashionable decorative element of Qajar architectural interiors, which was discussed in the press with enthusiasm as 'dazzling' and 'fairylike'. ${ }^{19}$ Under the official direction of Iran's imperial commissioner, Mirza Javad-Khan, the building had been constructed by two Tehrani workers, named in the press as 'Assa Ali' and 'Seda Ali', overseen by an architect or master-builder named in one press reference as Ustad Husayn 'Ali. ${ }^{20}$ [Figure 3].

By far the largest section in the Trocadéro park was that of Algeria, deliberately emphasising France's status as a colonial power. ${ }^{21}$ The Algerian representation was organized by its governorgeneral Antoine Chanzy and installed in an imposing structure with several historical crossreferences. Beyond the main building, independent commercial stands displayed more craftwork, such as highly-decorated chibouks, coffers (sanduq), carpets and jewellery. In total, the Algerian section numbered about 2,000 exhibitors. ${ }^{22}$

The Egyptian pavilion stood on the opposite side of the Trocadéro park. Initially intended to match the ancient Egyptian exhibits it was to have housed, this building was given a Pharaonic style on the specifications of the renowned Egyptologist Auguste Mariette (1821-1881), or Mariette-Bey. ${ }^{23}$ The impressive temple façade with square corner towers magisterially confirms the strong hold of Pharaonic imagery upon modern Egyptian visual identity. Within, the exhibits were to demonstrate economic progress achieved under the rule of Isma il Pasha (r.1863-79), and had been sent either by the Khedival schools and factories or by foreign-owned businesses established in Egypt. One corner tower was dedicated to photography, while the second contained displays of modern Egyptian craft industries, including cabinet-making (Egypt's wood industry employing a total of 16,000 people). The principal exhibit of the latter section was the furniture [Figure 4] presented by Giuseppe (or Joseph in non-Italian sources) Parvis (1831-1909). 
A cabinetmaker from Lombardy, Parvis had been based in Cairo since 1859: he had developed a successful factory specializing in 'Arabesque'-style furniture, and employed 50 workers (twothirds of them Egyptian) ${ }^{24}$. As one observer put it, revivalist production raised hopes that it might 'produce the happy result of serving the conservation and promotion of the beautiful designs of Arab art, which tended to disappear in Egypt ${ }^{25}{ }^{25}$ Two additional halls were devoted to a panorama of the Suez Canal (opened in 1869), and to the 1877 abolition of slave-trading in Egypt. Aside from these promotions of modern progress, Egypt had a further presence in the galleries inside the Trocadéro palace.

\section{A Palace for Loan Collections}

Among the many innovations at the 1878 Paris exhibition, was an entirely new building, the Palais du Trocadéro, located on the far bank of the river Seine, and facing the Palais du Champ de Mars. This consisted of a central section with a large concert hall, and two wings curved in a horseshoe, containing long galleries. In deliberate counterpoint to the modern manufacturing display halls opposite, the Trocadéro was to be dedicated to the past, with an extensive survey exhibition of 'ancient art'. Entitled 'l'exposition historique de l'art ancien', this was also referred to as the 'galerie de l'art rétrospectif'. ${ }^{26}$ The intention was to show the history of art production, century by century, in its widest variety, from the most humble to the most magnificent contexts. Nonetheless the intended survey rested upon a Eurocentric binary separation: the eastern wing of the Trocadéro palace was planned for European art, and the western wing to the arts of Asia, Africa, Oceania and the Americas. The show's full title was to be 'L'exposition historique de l'art ancien et de l'ethnographie des peuples étrangers à l'Europe'. Calls for national participation were however ineffective, and only Belgium and Spain responded in time. Within the host nation, regional museums and church treasuries contributed material, but the main Paris collections (such as the Louvre, Cluny and the Bibliothèque nationale) did not. Private collectors were more easily mobilized, but this swiftly complicated when major lenders insisted their collections be exhibited together. Eventually, the eastern wing was used for artworks (of any kind) owned by French (or France-based) collectors, and foreign submissions, including objects sent by Belgium, Sweden, Finland and Spain, were accommodated in the western wing occasionally referred to as 'galerie ethnographique'. The resulting displays were thus partnational and part-individual, and furthermore partly 'artistic' and partly 'ethnographic'. One press critic responded to this compromise with amusement, querying the inconsistent taxonomies, with French collectors lending 'foreign' art (and vice versa), and asking why metalwork and ceramics were classified 'ethnographic' if produced in Spain, China and Belgium, and yet counted as 'art history' if made in France, Italy and Germany. ${ }^{27}$

\section{The Egyptian Rooms at the Palais du Trocadéro}

Egypt was among the countries that joined late. Financial conditions had drastically changed for the country; spending with the magnificence seen for the 1867 Paris exhibition was no longer an option. According to Khedival correspondence in the National Archives of Egypt, Egypt's participation was decided on December 21, 1876 and the budget set at a minimum. Auguste Mariette was hired as General Commissioner on January $4,1877 .{ }^{28}$ He was instructed by the Khedive to depict Egypt through its material culture in three main phases of its civilisation, namely the Pharaonic, the Arab-Ottoman and the Khedival ('la dynastie régnante'). ${ }^{29}$ Installing at a late stage, this chronological sequence was divided in two: one section was hosted in the outdoor pavilion (already described above), and the other occupied a series of three galleries, 
right at the entrance of the western wing of the Palace. These Trocaderro rooms were to depict Ancient Egypt, Islamic Egypt and Modern Egypt, the contemporary Khedival era being itself divided between 'Equatorial Egypt' (modern Sudan) and central Egypt. The underlying concept was to illustrate the crafts that contributed to a global history of labour, the overarching theme of the 1878 exhibition.

On entering the western wing from the main entrance on Place du Trocadéro, visitors stepped first into the Equatorial Egyptian room (the first of two sections on Modern Egypt). ${ }^{30}$ Arms (panoplies of spears), musical instruments (drums), vessels, furniture and dress of the Sudanese people (recently colonised by Egypt), were displayed. Next came (central) Modern Egypt, with displays of textiles, jewellery, ceramics, arms and armour, and diverse utensils of recent manufacture. ${ }^{31}$ Adjoining this was Ancient Egypt: Mariette had commissioned large reproductions of murals depicting hunting scenes or other aspects of daily life, to illustrate society under the Pharaohs. Selected pieces, mostly plastercast replicas, were to show the development of antique sculpture. Ancient examples of artist's palettes and paint-boxes illustrated a long craft history, adhering to the 1878 theme of workmanship. Under a central canopy in Pharaonic style, stood a bust of the current Khedive.$^{32}$

The last room was for 'Arab and Ottoman Egypt'. This display was noted as 'L'Égypte des khalifes' or 'L'Égypte du Moyen Age' in the programme literature. ${ }^{33}$ Here, the Egyptian government had loaned three glass lamps and 'eight items from the Khedival Library'. ${ }^{34}$ Alongside Mamluk Qur'ans, six folios from the 1488 Bustan of the Persian poet Sa 'di, illustrated in Timurid Herat, were also on display, including the renowned painting depicting Yusuf and Zulaykha, the Qur'anic account of the Biblical prophet Joseph escaping Potiphar's wife, during his time as a slave in Egypt. ${ }^{35}$ The British director of the Egyptian Ministry of Public Instruction, the Arabist and numismatist Edward Thomas Rogers (1831-1884) (entitled Rogers Bey), loaned his collection of inscribed glass discs (then termed 'Cufic coins') that he had established were used as weights. ${ }^{36}$ Ambroise Baudry, who had been chief architect to the Khedive, contributed over 300 Ottoman tiles. The rest of display came predominantly from the personal collection of aristocrat Gaston de Saint-Maurice, who also curated this section of Egypt's display sequence. This gentleman had served at the Khedival court from 1868 to 1877 as grand equerry and was an avid Islamic art collector. No catalogue was published at the time, but visual and textual descriptions in the press [Figure 5], and moreover the extensive survival of the actual objects today, all help reconstruct its scope and rationale. Most of the Saint-Maurice exhibits would shortly enter public collections: in 1884, the South Kensington Museum finalized the acquisition of about 400 objects from Saint-Maurice. ${ }^{37}$ Other artefacts, such as the tiles loaned by Baudry, were purchased by the Louvre in $1898 .^{38}$

The packing inventory signed by Baudry in Cairo on March 12, 1878, most probably prior to sending his tiles off to Paris, numbered 331 pieces. ${ }^{39}$ Not all of these necessarily went on open display, but certainly a substantial amount did, if we are to believe the visual evidence of the display. The brilliantly colourful tiles [Figure 6] were presented against large wall-mounted carpets that reportedly 'belittled their brightness' ${ }^{40}$ The clash of colours must have been striking: the light and bright blue tones of Baudry's tiles over the dark red and deep brown tones of Saint-Maurice's carpets and kilims [Figure 7]. Their critical success in combination confirms the contemporary taste for vibrant polychromy. Identified today as Syrian, Baudry's tiles came from recently-demolished Cairo houses and were still referred to then as 'Persian tiles' or 'Rhodian tiles'. ${ }^{41}$ Featuring Persian manuscripts, Anatolian carpets and Syrian tiles, L'Égypte des 
Khalifes was not solely a display about historical Egyptian dynasties therefore, but reflected the collections, national and individual, that had formed within the country. The variety also confirms that such goods had been in motion across the wider region, through commercial activity and other network channels reaching into Egypt.

L'Égypte des khalifes included many examples of woodwork fittings, starting with a large mashrabiyya balcony ('from a harem') (not visible in Figure 5), and examples of composite panelling. This reflects a trend among Islamic art collectors in Cairo, French and Egyptian alike: salvaged medieval fragments of ivory and wood were commonly reconstructed in their original geometric pattern layouts, and then incorporated into modern woodwork frames. ${ }^{42}$ Eleven years previously, the architect-engineer Husayn Pasha Fahmi al-mi'mar, known as 'Dr Meymar' in the European sources, had exhibited similar salvaged examples at Egypt's pavilion constructed for the 1867 Paris exhibition. ${ }^{43}$ Baudry's house in Cairo, built in 1875-76, was replete with composite wood furnishings of this type; one of them, bearing copies of an inscription naming the fourteenth-century Sultan Barquq, now stands in the Mamluk galleries of the Museum of Islamic art in Cairo. ${ }^{44}$ As a commissioner for Egypt to the 1876 Centennial Exhibition in Philadelphia, Baudry may have been behind the display of a reconstructed minbar door out of detached carved polygons, re-mounted onto modern woodwork, with inscriptions bearing again the name of Sultan Barquq. Valued then at $\$ 14,000$, the door was considered a sensation, and was secured for Boston's newly-established Museum of Fine Arts. ${ }^{45}$ For his newly-designed Cairo mansion, Saint-Maurice followed this same trend, and engaged directly with the salvage, re-use and incorporation of architectural fittings. ${ }^{46} \mathrm{He}$ owned numerous doors consisting of a modern woodwork panel inset with carved Mamluk-period ivory and ebony plaques installed in complex geometric patterns [Figure 8]; several sets are visible in the print illustration of L'Égypte des Khalifes.

Less expected perhaps was the quantity of architectural plaster casts displayed. These were moulded, in pinkish plaster ('terre cuite rosée'), ${ }^{47}$ from relief-carved stone decoration from Mamluk Cairo monuments, such as the fourteenth-century mosque of Sultan Hassan and fifteenth-century architecture for Sultan Qaytbay [Figure 9]. One cast records only a quartersection of a dome, and is copied from a fifteenth-century house in Harat al-Rum (historically a Coptic quarter of Cairo); another replicates one quarter of a flat ceiling in the same house, possibly a previous dwelling of the Coptic Patriarchate ${ }^{48}$ Saint-Maurice had used both casts for the construction of the centrally-lit grand hall of his house in Cairo. Finally, specimens of inlaid metalwork were also on show. As a display, L'Égypte des Khalifes was therefore strongly representative of contemporary Revivalist trends in Cairo (echoing the work of furniture-makers such as Parvis), as well as being an exhibition of historical architectural design, fittings and furnishings.

\section{The Galerie Orientale at the Palais de Trocadéro}

For practical reasons of budget and readiness, relatively few national governments had (like Egypt) contributed to the historical art survey intended for the Trocadéro's extensive galleries, as well as the contemporary manufactures they may have displayed in the main hall across the river. Instead (as noted above), both gallery wings were completed by recourse to private 
collections, belonging to wealthy art connoisseurs living in France. This introduced two complications, which would necessarily adjust the Trocadéro's intended narrative sequence. Bonnaffé's light-hearted press sketch about private lenders ('les princes de la curiosité') concluded that it would surely be easier to classify (pre-Islamic Iranian) Sasanian coins than to coordinate so many private collections in one exhibition. ${ }^{49}$

The first complication was that some private lenders (such as the Russian diplomat Alexander Basilewski) preferred to display their artworks in one cluster, rather than dispersed within the sweeping chronological order imposed by a historical survey. The second issue was the essentially mixed and biographical character of private collecting. Private collecting is often directed to the conditions of domestic display, which at this period favoured variety. Diversity conveyed an owner's cosmopolitanism, as well as his or her discerning and selective taste. ${ }^{50}$ Thus, a private art collection in 1870s Paris was hardly likely to be limited to French or even European art. Sure enough, Liesville's Trocadéro sketch noted occasional Islamic artworks belonging to major lenders of European art, such as Basilewsky's Alhambra vase ('estimé un prix fou') while that of Lavoix noted the same collector's exceptional Kashan lustre vase ('un monument d'un intérêt capital et d'une beauté exceptionelle'). ${ }^{51}$

In mock despair, Bonnaffé complained that Middle Eastern carpets, inlaid metalwork and enamelled glass were to be found in several locations around the site. ${ }^{52}$ Nonetheless, the Trocadéro arrangements acknowledged and isolated this specific collecting trend, then current in France: such was the purpose of the Galerie Orientale, presented in a separate gallery on the first floor of the palace. Within this single display, the objects were culturally diverse, predominantly from Spain, Egypt, Syria, Turkey, Iran and India, in different media and ranging from the tenth to the sixteenth centuries. Their essential isolation was significant: raised on a hill across the river from the main halls, identified primarily by privileged European ownership and then further separated in an upper room, the artworks in the Galerie Orientale were carefully demarcated as pre-modern, precious and different. Such homogenized Other-ness suggests a single display role within elitist contemporary collecting circles, as private domestic installation. The uniting social aspect was an identifiable cult of Orientalist 'taste', expressed through personal aesthetic judgement, confirmed by ownership of exquisite objects. In addition, this wealthy peer group of art lovers (amateurs) was connecting with French academic scholarship of Middle Eastern languages, and thereby promoting a different understanding of Middle Eastern visual culture. The key players were Charles Schéfer, Henri Lavoix (1820-92) and Albert Goupil, who were all friends: a diplomat-linguist, a numismatist-journalist and a photographer-dealer, respectively. ${ }^{53}$ Over the years, they had advanced academic interpretations of privately-owned material, reading inscriptions and citing historical sources, and embellished the profile of private collectors. Schéfer's own art collection was a primary resource. Lavoix and others drew from their own specialist knowledge to publish illustrated accounts of specific objects in the art press. ${ }^{54}$ So when in 1878 for example Lavoix published images of two enamelled glass mosque lamps loaned by André [Figure 10], he could refer to ten more such lamps in other collections, provide full translations of all their inscriptions and explain both the blazon system and genealogy of the Mamluk sultans. As a coin specialist, such direct reporting was key to his textbased methodology. More generally, Lavoix's prose regularly cited texts of Islamic history, from Umayyad, 'Abbasid, Fatimid and Mamluk sources. In particular he conveyed a deep enthusiasm for 'Abbasid Baghdad - a gilded era of cosmopolitan privilege, aesthetically-minded patronage, and exquisite craft production - 'Abbasid history he observed, was worthy of a great novel. ${ }^{55}$ Aside from Mamluk titulature, dynastic history was rarely specific to the artworks under discussion: instead Lavoix (like Goupil and others) was promoting an overarching narrative about 
Middle Eastern culture which drew from his own professional circuit. For him, this prism was the published corpus of edited translations of Middle Eastern historical literature, i.e. the research generated at the École des Langues Orientales Vivantes in Paris.

In different ways, the impact of Goupil's 1878 display had long been choreographed. Through press comment and the Trocadéro position, Lavoix and Goupil conveyed the impression that the Galerie Orientale now laid bare an intimate social network of well-travelled and distinguished friends. Lavoix wrote an article for La Gazette des Beaux-Arts, which is composed as an open letter to Charles Schéfer, affectionately remembering the former diplomat's travels in Syria, and his wonderful and influential art collection. ${ }^{56}$ Lavoix also noted how Schéfer had anticipated the current collecting trend: 'les arts musulmans' had once seemed inaccessible to Europeans, because the language barrier meant that only trained scholars could access their meaning ('c'était affaire des savants'). The previous Paris exhibition in 1867, Lavoix recalled, had since marked a new shift in French taste, and he thanked ten collectors by name for allowing scholars access to their 'treasures', in the intervening years. ${ }^{57}$ This 1878 narrative was ultimately also a calculated act of commercial exposure, guaranteed to stimulate demand and inflate market value, by emphasising the social status of collectors (or rather clients). Goupil would continue to develop the Paris market for star objects, presented in similar 'orientalist' architectural interiors, before his early death in 1884 .

In 1878 , over thirty individuals loaned to Goupil's display. ${ }^{58}$ Ranging from manuscripts to carpets, these objects must have been wall-mounted or freestanding. One large display-case featured only the collections of Delort de Gléon and Goupil himself. ${ }^{59}$ However there is no visual record of the gallery layout, nor any complete catalogue list. Instead separate images of six objects were published in Lavoix's account of the display, in La Gazette des Beaux-Arts: two enamelled glass mosque lamps belonging to Edouard André, a gilded copper mosque lamp from Mamluk Syria belonging to Charles Schéfer, a gilded and enamelled sword hilt from Spain belonging to the Marquis de Villaseca, ${ }^{60}$ a Spanish ivory casket (dated 355H/965AD) then belonging to Goupil himself, and a repoussé gold bracelet belonging to the art-dealer Stanislas Baron. Such images underline a special status for 'star objects' that Lavoix emphasised were already familiar within the circle of collectors: with publication, these would now become increasingly well-known in reproduction, either as photographs, prints or colour plates based on designers' drawings. This visual celebrity focused attention upon the objects, signalling their intrinsic aesthetic as well as economic value: the Spanish ivory casket on loan from Goupil, would be reproduced again seven years later for the published report of his estate sale. ${ }^{61}$ Contemporary designers were all the more likely to produce replicas of these celebrated objects, such as the footed glass bowl (reportedly bought by Schéfer from his barber in Damascus), sketched by Adalbert de Beaumont in 1866, and copied by Phillippe-Joseph Brocard's Paris glassworks in $1869 .{ }^{62}$

\section{Presenting Safavid Carpets in Goupil's Salon}

The 1878 Galerie Orientale was therefore part of an established trend in Paris, in which academic linguistic research and aesthetic art-collecting had maintained a symbiotic relationship. This produced a clear preference for art objects bearing inscriptions, which introduces a specific group in Goupil's salon. One of the revelations of the Paris exhibition, particularly for industrial museums, was the design quality of the Safavid Iranian carpets on show. Describing Goupil's Trocadéro display, Lavoix had praised the 'marvellous' carpets with inscriptions in the borders, 
belonging to Goupil, the Orientalist painter Jean-Léon Gérome (Goupil's brother-in-law) and the two Rothschilds. ${ }^{63}$ His comment (together with other secondary accounts) plausibly links the 1878-displayed carpets (for which no direct record survives) with three late-sixteenth-century carpets which in 1885 were photographed wall-mounted in the Goupil family firm's Paris showroom, while multiple less-rated carpets covered the floor. Inscribed with Persian poetry, these metal-brocaded carpets have now been identified as Safavid court objects, used as diplomatic gifts in the 1560s. As photographed in 1885, they are seen on Goupil's salon walls flanked by detached door-panels (apparently Mamluk minbar doors) with geometric ivory inlaywork, of the type exhibited by Saint-Maurice in 1878, and Baudry in Philadelphia 1876 (as noted above) [Figure 11]. Wall-mounted in sequence, both types of objects are converted to a new architectural role: to enclose an interior space. The 1885 room was the thematic 'Salon Oriental' in the Goupil company's main premises on rue Chaptal in Paris, which was matched by their 'Salon Occidental' of European Renaissance art and furnishings. At the time, these valuable Safavid carpets were rated with fine oil painting, which explains their vertical display at Goupil's showroom, one of the earliest known instance of such an installation. ${ }^{64}$ This aestheticizing fashion gained currency in the following decades in private interiors as well as in museum galleries, progressing in step with the rising commercial prices for 'classical' Middle Eastern carpets and even carpet fragments. ${ }^{65}$ Following Goupil's death in 1884, the three carpets were sold onwards to collections in France and America. ${ }^{66}$ In the more immediate aftermath of the 1878 Paris exhibition though, it appears that more examples of this specific Safavid carpet category were acquired by other collectors: in London, George Salting had purchased one by 1883 , when he loaned it on a long term basis to the South Kensington Museum. ${ }^{67}$ It may be significant that this critical reception for the so-called 'Salting Carpets' seems to commence only from 1878: the group is now understood as having been sold out of the Topkapi Palace treasury in Istanbul, during the city-wide duress caused by the Russo-Turkish war of $1877-8 .^{68}$ If so, this would wholly confirm the long-acknowledged effect of geopolitical instability upon the international art market: here, a transformative category of art object was reportedly exported because military action was anticipated, and feared.

Two years after Paris, a junior curator at the South Kensington Museum remembered the critical impact of Goupil's display:

The remarkable loan collection of antique oriental carpets in the Trocadero Gallery of the Paris Exhibition of 1878 first presented these objects to public notice, and it was then discovered that a high class branch of fine art production had hitherto been utterly ignored by Museum administrations, although well known to amateurs, and commanding prices on a level with the most valued productions of the middle ages. ${ }^{69}$

This epiphany would alter the acquisition policy for 'Persian carpets' at the South Kensington Museum, with the authorities finally agreeing to buy these expensive collectors' items. $^{70}$ Initially South Kensington borrowed important examples, from George Salting (as noted), and others. ${ }^{71}$ The museum also published Art Portfolio series of loaned (as well as accessioned) carpets, providing affordable colour images for designers' reference. ${ }^{72}$ In France, most of Goupil's carpets had also passed into national collections linked with design industries: he bequeathed one to the Gobelins, and the collector Jules Maciet would donate two from Goupil's 1888 estate sale directly to Musée des Arts Décoratifs. ${ }^{73}$ 


\section{Conclusions: the aesthetic appeal of immersive displays}

A number of conclusions can be drawn from this attempt to reconstruct the displays of Middle Eastern material culture at the 1878 international exhibition in Paris. The first addresses the evocative diversity of architectural settings within which artefacts were presented to the public: commercial stalls, national pavilions, themed exhibitions and loan displays. Formal categorization was still uncertain, and often haphazard: this is best illustrated by the way in which Middle Eastern items stood among Spanish and Belgian painting and sculpture in the 'ethnographic' wing of the Palais du Trocadéro.

Secondly, the range of exhibits characterized a new appreciation of Islamic art. While this had started in the 1860s, in 1885 Henri Lavoix would reflect that the 1878 exhibition had marked a shift in the public perception of historical Middle Eastern artworks, from obscure academic fare to objects of celebrated social distinction, now finally enshrined in private ownership and domestic display in 'themed rooms'. Goupil's 1878 Trocadéro display had been pivotal in changing this social attitude, and by 1885 , Lavoix would praise a situation in which 'treasures were [now] in the service of erudition', because refined collectors had now assembled 'these precious documents' for scholars to study: the collectors 'are our first and most useful collaborators' ${ }^{74}$ The confined architectural interiors of French domestic display had, by this reasoning, transformed French research on Middle Eastern art history: if so, these displays had certainly defined and also limited the scope of such scholarship.

Thirdly, most installations were architectural in reference, whether as actual salvaged fragments, reconstructed rooms from (French) private house collections, or as modern replicas staged for the Rue des Nations facades and the Trocadéro park pavilions alike: architectural framing played a crucial part in this reappraisal. Deriving from a decade lived in Cairo, Saint-Maurice's housecollection was both diverse and distinctly personal: its presentation at Trocadéro was admired by both amateurs (art-lovers) and the general public. When South Kensington curators saw the 1878 installations, they were persuaded not just by the art objects themselves, but by the intimate social character of private installations. This London museum purchased (much of) the Saint-Maurice collection (in 1884), and (from 1883 onwards) pursued carpets of the calibre of both Robinson and Goupil's displays - for the first time. Located in these specific 1878 displays, Iranian carpets signified imagined contexts of Indian royal architecture (echoed in the British India pavilion) and Paris salon society (in Goupil's exclusive gallery) respectively.

As an interior design trend, the installation of Middle Eastern architectural salvage was not entirely new in Europe. It pertained to a culture, and almost an industry, of medieval architectural reuse that can be traced back to the 1830s in France with the reclaiming and refurnishing of the abbey of Cluny by Alexandre du Sommerard (today the Musée de Cluny, in Paris). ${ }^{75}$ Neither was the phenomenon restricted to 'Islamophilia': the taste for Japonisme offers strong parallels, as it generated similar themed interiors in Japanese style. Perhaps significantly, both trends were typically pursued by wealthy bachelor aesthetes. ${ }^{76}$ It has been hypothesized that bachelorhood, and moreover the outright rejection of domesticity, were the key determinants for this specific, highly gendered, collecting culture. ${ }^{77}$ Most of the collectors surveyed in this article fit this homosocial pattern.

In Khedival Cairo, historic salvage was already part of the modern state activity of demolitions through the old city, just as (paradoxically) modern Revivalist imitations were used to demonstrate the nation's future potential - at foreign exhibitions such as Paris 1878, and in local industry including Khedival court architecture. This trend may have accelerated removals from demolition sites, and the experimental reuse of salvaged fragments and plaster casts, re-fitted 
into modern furniture and private architectural settings. The Revivalist craft industry emerged in Cairo, at the same time that European designers and craftsmen were imitating Middle Eastern objects encountered at international exhibitions, as well as private collections, across Europe. Egypt's government-sponsored displays whether historic or modern, demonstrate this parallel process, with salvaged fragments and revival products typically exhibited side by side.

The 1878 Paris exhibition had therefore proposed 'Islamic art' as something architecturally defined and contained. In private circles, access to a privileged social world of 'themed rooms' was controlled, but increasingly available to academic scholarship, Revivalist designers and (now) the wider exhibition-going public. Possession of such distinguished objects now implied the privileged status of elite travel, intellectual knowledge and personal taste. As momentum grew, museum collections began to absorb the presentation modes of tasteful private interiors, along with their typical art contents, often acquiring diverse collections wholesale - along with salvaged architectural fragments, revivalist composites and plastercast replicas. Architectural context was the intimate and persuasive signifier, confirming the art status of a material culture broadly unfamiliar to European public opinion, and encapsulating (and overlooking) its complex diversity within a single 'themed room'.

\section{Images}

Figure 1:

Figure 1: 'The Indian Court, Paris Exhibition, 1878', frontispiece illustration to George C.M. Birdwood, Handbook to the British Indian Section, London: Offices of the Royal Commission, 1878.

Figure 2:

Figure 2: Émile Bergerat, 'Maison Vincent Robinson \& Co', Les Chefs-D'Oeuvre d'Art à l'Exposition Universelle de 1878, Paris: Ludovic Baschet, 1878, p.172.

Figure 3:

Figure 3: 'Perse: Palais Persan', in Glucq, L'Album de l'Exposition 1878, Paris: 1878, pl.61.

Figure 4:

Figure 4: Cabinet with revivalist inlaid decoration made by Giuseppe Parvis, Illustrated catalogue of the Paris International exhibition, London: Virtue, 1878, p. 8.

Figure 5:

Figure 5: Saint-Maurice's display, entitled L'Égypte des khalifes', here published as 'L'Exposition retrospective égyptienne dans le parc du Trocadéro', L'Illustration, 72/1872, 2 November 1878, $p$. 277.

Figure 6:

Figure 6: Two tiles, probably Syria, sixteenth century, from the Cairo collection of Ambroise Baudry, Paris: Louvre, OA 4047/66, 4047/89.

Figure 7: Courtesy of the Trustees of the Victoria and Albert Museum

Figure 7: Carpet, Qashqa'i, signed Yusuf 'Ali, Fars province, Iran, c.1850-1875, London: V\&A, 1013-1884. 
Figure 8:

Figure 8: Door with inlaid geometric design, Cairo, fourteenth-century inlaid panels mounted within nineteenth-century frame, formerly in the house collection of Gaston de Saint-Maurice, Cairo, Edinburgh: National Museum of Scotland, A.1884.2.1.

Figure 9: Courtesy of the Trustees of the Victoria and Albert Museum

Figure 9: Plaster cast, moulded in London from the original Cairo cast of Gaston de SaintMaurice, moulded from decorative stonework of the mosque of Sultan Hassan, London: V\&A, REPRO.1884-827.

Figure 10:

Figure 10: Mamluk enamelled glass mosque lamp, from the collection of Edouard André, published in Henri Lavoix, 'La Galerie Orientale de Trocadero', Gazette des Beaux-Arts, 18/5, 1878, p. 777.

Figure 11: (C) INHA, Dist. RMN-Grand Palais/Martine Beck-Coppola.

Figure 11: Édmond Bénard, Goupil's salon oriental, photograph, c.1885, Paris, Bibliothèque de I'INHA, Intérieurs privés d'artistes. Ateliers d'artistes, 1880-1910, 4 Phot 021, $n^{\circ} 35$.

\footnotetext{
${ }^{1}$ We use the term Middle East to encompass the region of west Asia spanning Turkey, the Arab world (including Syria, Iraq and Egypt), Iran and Afghanistan. See discussion in Hassan Hanafi, 'The Middle East, in Whose World? (Primary Reflections)', in The Middle East in a Globalized World. Papers from the Fourth Nordic Conference on Middle Eastern Studies, Oslo 1998, eds. B.O. Utvik and K.S. Vikor (Bergen: Nordic Society for Middle Eastern Studies, 2000), 1-9.

${ }^{2}$ Frezouls (1878), Plan-guide définitif de l'Exposition internationale de 1878..., Paris: Bibliothèque nationale de France, département Cartes et plans, GE C-7272 (A)', http://gallica.bnf.fr/ark:/12148/btv1b530856679?rk=64378;0 . Accessed 27 March 2018.
}

${ }^{3}$ Zeynep Çelik, Displaying the Orient: Architecture of Islam at Nineteenth-Century World's Fairs, (Berkeley: University of California Press, 1992); Exhibiting the Middle East: Collections and Perceptions of Islamic Art, ed. Linda Komaroff, Ars Orientalis 30 (2000); Rémi Labrusse, 'De la collection à l'exposition: les Arts de I'Islam à Paris (1864-1917)', in Purs décors, Arts de I'Islam, Regards du XIX siècle, ed. Rémi Labrusse (Paris: Arts Décoratifs, 2007), 64-74; Chris Dercon, Léon Krempel, and Avinoam Shalem, eds., The Future of Tradition- the Tradition of Future (London and New York: Prestel, 2010).

${ }^{4}$ Henri Lavoix, 'La Galerie orientale au Trocadéro, à Monsieur Charles Schéfer', Gazette des Beaux-Arts 18/5 (1878): 781, 784, 787.

${ }^{5}$ Mehrangiz Nikou, 'National Architecture and International Politics: Pavilions of the Near Eastern Nations in the Paris International Exhibition of 1867' (Ph.D. diss., Columbia University, 1997).

${ }^{6}$ István Ormos, 'Cairo Street at the World's Columbian Exposition of 1893 in Chicago: A New, Fresh Reading', in Dialogues artistiques avec les passés de l'Égypte: une perspective transnationale et transmédiale, ed. M. Volait and E. Perrin (Paris: InVisu, 2017), http://journals.openedition.org/inha/7201. 
${ }^{7}$ Mark Crinson, Empire Building, Orientalism and Victorian Architecture (London: Routledge, 1996); Anna McSweeney, 'Versions and Visions of the Alhambra in the Nineteenth-Century Ottoman World', West 86 ${ }^{\text {th }}$ 22:1 (2015): 44-69.

${ }^{8}$ Mercedes Volait, Fous du Caire: Architectes, excentriques et amateurs d'art en Égypte (18671914) (Apt: L'Archange minotaure, 2009).

${ }^{9}$ On the impact of nineteenth-century 'immersive installations' of Islamic art on later museum display policies, and in particular for vertical carpet installation, see Solmaz Mohammadzadeh Kive, 'The Exhibitionary Construction of the "Islamic Interior»', in Oriental Interiors: Design, Identity, Space, ed. J. Potvin (London: Bloomsbury Academic, 2015), 39-58 (discussed further below).

${ }^{10}$ Moya Carey, 'Appropriating Damascus Rooms: Vincent Robinson, Caspar Purdon Clarke and Commercial Strategy in Victorian London', in À l'Orientale... , ed. F. Giese et al. (Leiden: Brill, forthcoming).

${ }^{11}$ Jules Creux, 'Pavillon anglo-indien', L'Exposition universelle de 1878 illustrée, 164, September, $1878,869$.

${ }^{12}$ Anon., 'Paris Exhibition [from a correspondent]', Journal of the Society of Arts, 26, May 10, $1878,549$.

${ }^{13}$ George C.M. Birdwood, Handbook to the British Indian Section (London: Offices of the Royal Commission, 1878), 99.

${ }^{14}$ Birdwood, Handbook, 94.

${ }^{15}$ This is also argued of Robinson's presentation of Middle Eastern objects persuasively 'framed' within the Damascus Room installed in his London premises, all sold to the South Kensington Museum in 1880, Carey, 'Appropriating Damascus Rooms'.

${ }^{16}$ The palace's [...] siting, size, and form as a whole created an image of France as a protective father/master with his arms encircling the colonial village (Zeynep Çelik and Leila Kinney, 'Ethnography and Exhibitionism at the Expositions Universelles', Assemblages 13 (1990): 37). The pavilions in the Trocadéro park represented Egypt, China, Iran ('Persia'), Sweden, Norway, Tunisia, Morocco, and Algeria.

${ }^{17}$ Exposition Universelle, Guide-itinéraire du visiteur (Paris: E. Dentu, 1878), 260.

18 Jules Creux, 'Le pavillon persan', L'Exposition universelle de 1878 illustrée 142, July, 1878, 706; Adelin, 'Le palais persan', L'Exposition universelle de 1878 illustrée 140, 1878, 685.

${ }^{19}$ Anon., 'Letters from Paris', The Illustrated Paris Universal Exhibition, August 3, 1878, 149; Anon., L'Exposition universelle de 1878, 15.

${ }^{20}$ Creux, 'Pavillon persan',706. The architect is named 'Hussein 'Ali of Isfahan, who had also constructed the pavilion at the great Vienna Exhibition [in 1873]' in A. Houtum-Schindler and L. de Norman, A Diary kept by his Majesty the Shah of Persia, during his Journey to Europe in 1878 (London: Richard Bentley, 1879), 168. On South Kensington's request for the two 'Persian master masons' to visit London, see Abraham Thomas, 'The Orient and Ornament at the South Kensington Museum', in Art and Design for All. The Victoria and Albert Museum, ed. J. Bryant (London: V\&A, 2011), 95-6; Moya Carey, Persian Art. Collecting the Arts of Iran for the V\&A (London: V\&A, 2018), ch.1.

${ }^{21}$ Algeria was declared an integral part of France in 1848, and divided into three départements.

${ }^{22}$ The Paris exhibition of 1878, An Illustrated Weekly Review of Trade, Industry, Agriculture and Art, 19 October 1878, front page; Royal Commission for the Paris Exhibition (1878), Report of Her Majesty's Commissioners for the Paris Universal Exhibition of 1878 to the Queen's most excellent Majesty (London : HMSO, 1880), 627. 
${ }^{23}$ Foreign high-rank officials in the Egyptian Government were granted the honorific title of Bey or Pasha as a reward for their achievements.

24 Illustrated catalogue of the Paris International exhibition (London: Virtue, 1878), 8, 66 (illustrating four of Parvis' cabinets).

${ }^{25}$ Gustave Delchevalerie, 'L'Égypte agricole, industrielle et artistique', in Études sur l'exposition universelle Paris 1878, Annales et archives de l'industrie au XIX siècle 9 (Paris : Librairie scientifique, industrielle et agricole E. Lacroix, 1878), 365-452 (434).

${ }^{26}$ Alfred Frigoult de Liesville, 'L'exposition historique de l'art ancien', Gazette des Beaux-Arts 18/1 (1878), 5-16.

${ }^{27}$ Edmond Bonnaffé, 'Au Trocadéro. Causerie', Gazette des Beaux-Arts, 18/3 (1878): 321-326 (322).

${ }^{28}$ National Archives of Egypt, Dar al-Watha'iq, Box 36 g Exhibitions, letter from M. Barrot to Riaz Pacha, December 20, 1876; letter from Baron des Michels to Ferdinand Barrot, January 4, 1877.

${ }^{29}$ Exposition universelle de Paris, 1878. Auguste Mariette-Bey, La Galerie de l'Égypte ancienne à l'exposition rétrospective du Trocadéro, description sommaire, Exposition universelle de Paris (Paris: F. Pichon, 1878), 5.

${ }^{30}$ The exact sequence of rooms is described in Alfred Frigoult de Liesville, Coup d'œil général sur l'exposition historique de l'art ancien (palais du Trocadéro) (Paris: Honoré Champion, 1879), 5162.

${ }^{31}$ Liesville, Coup d'œil, 52-53; Les Merveilles de l'Exposition de 1878 : histoire, construction, inauguration, description détaillée des palais, des annexes et des parcs (Paris: Librairie contemporaine, 1879), 731; L'Exposition en poche : guide pratique illustré (Paris: office des Guides Conty, 1878), 166-7).

${ }^{32}$ Arthur Rhoné, 'L'Égypte antique au Trocadéro', Gazette des Beaux-Arts 18/4 (1878) : 441-469.

${ }^{33}$ Arthur Rhoné, 'La galerie des Antiquités égyptiennes à l'Exposition' , L'Illustration, Journal Universel, November 2, 1878, 283.

${ }^{34}$ National Archives of Egypt, Dar al-Watha'iq, Box $36 \mathrm{~g}$ Exhibitions, Letter from Ismail Ayoub, the minister of Education to khedive Ismail, January 24, 1877.

35 'Exposition universelle de 1878', Journal des débats, July 10, 1878, 2.

${ }^{36} \mathrm{His}$ research was based on studying his own collection, and that of Rev. Greville Chester, see Edward Thomas Rogers, 'Unpublished Glass Weights and Measures', The Journal of the Royal Asiatic Society of Great Britain and Ireland 10/1 (January 1878), 98-112.

${ }^{37}$ The collection stayed in Paris after the 1878 Exhibition as a loan to the Union central des arts décoratifs, before being purchased by the South Kensington Museum (London: V\&A Archive, Saint-Maurice, MA/1/S180).

${ }^{38} 279$ tiles were purchased. Pierrefitte-sur-Seine: Archives centrales des musées nationaux, 1-BB32 (1896-1897) Comité consultatif des Musées nationaux, Procès-verbaux des séances, Séance du 25 novembre 1897 (f. 122).

${ }^{39}$ Paris: Archives of Union Centrale des arts décoratifs, B2/3, Cahier manuscrit. 'Collection de faïences décoratives recueillies au Caire par les soins de M. Ambroise Baudry', Total de 331 pièces, "dressé au Caire, le 12 mars 1878».

${ }^{40}$ L'Exposition universelle de 1878 illustrée, 143, July 1878, 709.

${ }^{41}$ The tiles had therefore already been salvaged from Syrian architecture, and brought to Egypt, see Rhoné, 'La galerie', 283. Vanke sources the original Persian/Iznik confusion to Brongniart and Riocreux at Sèvres (F.J. Vanke, 'British Cultural and Aesthetic Relationships with Decorative Arts of the Islamic Orient, with Special Reference to Ceramics, 1851-1914', (Ph.D. diss., Camberwell College of Arts, 1998) :133, citing Alexandre Brongniart and Denis-Désiré Riocreux, Description 
méthodique du Musée céramique de la manufacture royale de porcelaine de Sèvres (Paris: Leleux, 1845), 186, 677).

${ }^{42}$ Volait, Fous du Caire.

${ }^{43}$ The South Kensington Museum bought heavily from 'the Meymar Collection' at Paris in 1869, including fragments of the Lajin minbar which were similarly re-assembled in a modern framework.

${ }^{44}$ Marie-Laure Crosnier Leconte and Mercedes Volait, L'Égypte d'un architecte; Ambroise Baudry (1838-1906) (Paris: Somogy, 1998), 88; Cairo: Museum of Islamic Art: inv. 23767 (Bernard O'Kane, The Illustrated guide to the Museum of Islamic Art in Cairo, with contributions by Mohammed Abbas, Imam R. Abdulfattah (Cairo: The American University in Cairo Press, 2012), 134).

${ }^{45}$ Boston: MFA, inv. 77.1 (Laura Weinstein et al., Ink, silk \& gold : Islamic art from the Museum of Fine Arts, Boston (Boston: MFA Publications, 2015), 49).

${ }^{46}$ Mercedes Volait, Maisons de France au Caire, Le remploi de grands décors mamelouks et ottomans dans une architecture moderne (Cairo :Publications de l'Institut français d'archéologie orientale, 2012).

${ }^{47}$ Liesville, Coup d'œil, 59.

${ }^{48}$ Julien Auber de Lapierre, 'Le Musée copte du Caire, une utopie architecturale', Annales islamologiques 50 (2017), 235-266.

${ }^{49}$ Bonnaffé, 'Causerie', 326.

${ }^{50}$ For example the objects displayed by Émilien de Nieuwerkerke (1811-1892), the director of France's Imperial Museums under Napoléon III, in his apartments at the Louvre, on public viewing every Friday; see Charles Giraud, Intérieur du cabinet du directeur général des musées impériaux, 1859, Paris: Musée du Louvre, inv. RF1990-4; Théophile Gautier, 'Les soirées du Louvre', L'Artiste, January 31, 1858, 69-70.

${ }^{51}$ Liesville, 'L'exposition historique', 11; Lavoix 'La Galerie Orientale', 791.

${ }^{52}$ Bonnaffé, 'Causerie', 323.

${ }^{53}$ For biographies, see Labrusse, Purs décors, 314 (Goupil) and 321 (Schéfer). Henri Lavoix was a curator at the department of medals and antiques, at the Bibliothèque Nationale de France, and wrote the catalogues for the Islamic coin collections. He was also a theatre critic (writing under the pseudonym Savigny) for the newspaper L'Illustration.

${ }^{54}$ Louis Viardot, 'Quelques notes sur la peinture et la sculpture chez les musulmans : Lettre à M. le directeur de la Gazette des beaux-arts', Gazette des Beaux-Arts 1/6 (1869): 556-559; Florian Pharaon, 'La peinture et la sculpture chez les musulmans', Gazette des Beaux-Arts 1/5 (1869): 442-446; Henri Lavoix, 'Les arts musulmans [1]: de l'emploi des figures', Gazette des Beaux-Arts 12/2 (1875): 97-113; 'Les arts musulmans [2]: de l'emploi des figures', Gazette des Beaux-Arts 12/4 (1875): 312-321; 'Les arts musulmans: de l'ornementation arabes dans les œuvres des maitres italiens', Gazette des Beaux-Arts, 16/1 (1877): 15-29.

${ }^{55}$ Lavoix, 'La Galerie orientale', 773. This is praise indeed coming in late nineteenth-century France, in the epic times of Émile Zola, Victor Hugo and Alexandre Dumas. A familiar and fallible trait in historiography is to overlay one's own time with one's period of study.

${ }^{56}$ Lavoix, 'La Galerie orientale', 769.

${ }^{57}$ Lavoix, 'La Galerie orientale', 770.

${ }^{58}$ Though not exhaustive, the following lenders' names are recorded: Aumont, Stanislas Baron, Alexander Basilewksy, Ambroise Baudry, Gustave de Beaucorps, Louis Bertrand, Alfred Beurdeley, Michel Boy, Stanislas von Chlebowski, Wladislaw Czartoryski, Davillier, Alphonse 
Delort de Gléon, Didot, Dreyfus, Dutuit, Joseph Fau, Gayet, Albert Goupil, S. de Gunzbourg (the only female lender), Jacquemart, Charles Mannheim, Georges Martin, Posno, Eugene Piot, C. Rogier, Edmond and Gustave de Rothschild, Ben Sadoun, Charles Schéfer, Eugene de Thuisy, Van Elven.

${ }^{59}$ Lavoix, 'La Galerie orientale', 785.

${ }^{60}$ New York: Metropolitan Museum of Art, 1983.413.

${ }^{61}$ The object was bought for the Union Central des Arts Décoratifs, where it remains today (Paris: UCAD, 4417).

${ }^{62}$ Bought by Edward C. Moore and later bequeathed to the Metropolitan Museum (New York: Metropolitan Museum of Art, inv.91.1.1538), the Brocard version was purchased for South Kensington Museum in 1869 (London: V\&A, 1777-1867), sketched in E. Collinot and A. De Beaumont, Ornements de la Perse. Recueil de dessins pour l'art et l'industrie, (Paris: Canson, 1880), pl.13. See images and discussion in Rémi Labrusse, Islamophilies. L'Europe moderne et les arts de I'Islam (Paris: Somogy, 2011), 272-3. Labrusse characterizes these celebrity object biographies as 'une carrière d'objet de prestige' (Labrusse, Islamophilies, 262).

${ }^{63}$ Lavoix, 'La Galerie orientale', 788.

${ }^{64}$ Paul Mantz, 'La collection Albert Goupil', Le Temps, April 22, 1888.

${ }^{65}$ Mohammadzadeh Kive, 'The Exhibitionary Construction'. Other instances of wall-mounting Safavid-era carpets are recorded in Rome 1883, of the collector Alessandro Castellani (London: V\&A Archive, Castellani, MA/1/C713/1, referring to V\&A carpet 721-1884, quoted in Carey, Persian Art, 202), and in London 1885, for the Burlington Fine Arts Club exhibition, Persian and Arab Art.

${ }^{66}$ Baltimore: Walters Art Gallery, 81.3 (purchased from Charles Tyson Yerkes estate sale), Lyons: Musée historique des tissus, 24619, and Paris: Musée des arts décoratifs, 4406. A fourth carpet, an uninscribed all-silk Kashan example, also hung in the Goupil salon (now Paris: Musée des Gobelins 1534) (all four identified in Susan Day, 'The Artist's Eye. Carpet and Textile Collections of the Orientalists', Hali 126 (2003), 102-104).

${ }^{67}$ London: V\&A, T.402-1910 (acquired as part of the Salting Bequest). With relatively early South Kensington publicity, later art historiography has now labelled this entire (and diverse) group as 'Salting Carpets': Murray L. Eiland and Robert Pinner (eds.), The Salting Carpets, Oriental Carpets and Textile Studies, 5/2 (1999).

68 John Mills, 'The Salting Group: A History and A Clarification', Oriental Carpets and Textile Studies 5/2 (1999), 1-17; Carey, Persian Art, 258 n.87. One was bought directly in Istanbul by the Russian ambassador (Prince Lobanov-Rostovsky) in 1878 (now St Petersburg: Hermitage). Not all can have been de-accessioned from the Topkapi during the 1877-8 war: a Czartoryski-owned carpet (now Krakow: Czartoryski Museum) was recorded in Poland in 1809, when the French scholar and diplomat Amadée Jaubert read the inscription (Mills, 'The Salting Group'. 7): it is not known whether Czartoryski displayed this carpet with the rest of his art collection in the Trocadéro palace, in 1878.

${ }^{69}$ Caspar Purdon Clarke, 'Report' dated July 31, 1880, London: V\&A Archive, MA/1/R1314/1.

As noted earlier Caspar Purdon Clarke (1846-1911) had contributed to the 1878 Paris exhibition as architect of the British-Indian pavilion and official commercial agent for Britain. In 1886, he also negotiated to buy one of Robinson's Paris-displayed 'Afghan' carpets for South Kensington's permanent collection: London: V\&A, I.S.12-1886 (Carey, Persian Art, 204-6, n.97). 
${ }^{70}$ Only after this did South Kensington purchase Safavid-era carpets, such as the Ardabil Carpet (dated 1539-40) acquired in 1893 (Jennifer Wearden, 'Acquisition of Persian and Turkish Carpets by the South Kensington Museum', in Discovering Islamic Art. Scholars, Collecting and Collections, 1850-1950 , ed. S. Vernoit (London: I.B. Tauris, 2000): 96-104; P.L. Baker, 'Safavid Carpets and Nineteenth-century European Notions', in Safavid Art and Architecture, ed. S. Canby (London: British Museum, 2002): 77-82; Carey, Persian Art, ch.4 passim).

${ }^{71}$ Carey, Persian Art, 217, n.137.

${ }^{72}$ South Kensington Museum, Portfolio of Persian Art, parts 4-7, 14-17 (London: Griggs, 1884-93); Carey, Persian Art, 211-12.

${ }^{73}$ Susan Day, 'Jules Maciet et le goût du tapis islamique', in Purs décors, Arts de l'Islam, Regards $d u X I X^{e}$ siècle, ed. R. Labrusse (Paris: Arts Décoratifs, 2007), 302-09.

${ }^{74}$ Henri Lavoix, 'La Collection Albert Goupil. II. L'art oriental', Gazette des Beaux-Arts 32/4 (1885), 292.

75 On Goupil's installations in connection with those of Saint-Maurice, see Mercedes Volait, 'Les intérieurs orientalistes du comte de Saint-Maurice et d'Albert Goupil: des "Cluny arabe " au Caire et à Paris à la fin du XIX ${ }^{\mathrm{e}}$ siècle', in The Period Rooms. Allestimenti storici tra arte, collezionismo e museologia, eds. S. Costa, D. Poulot and M. Volait (Bologna: Bologna University Press, 2017), 103-114. On Sommerard's enterprise, see Elisabeth Emery and Laura Morowitz, 'From the living room to the museum and back again: the collection and display of medieval art in the fin de siècle', Journal of the History of Collections 16/2 (2004), 285-309.

${ }^{76}$ Christopher Reed, 'Bachelor Quarters: Spaces of Japonisme in Nineteenth-century Paris', in Potvin, Oriental Interiors, n.9. For a family memoir on Charles Ephrussi, a noted art-collector in Paris society, see Edmund de Waal, The Hare with Amber Eyes, A Hidden Inheritance (London: Chatto \& Windus, 2010).

${ }^{77}$ Christopher Reed (ed.), Not at home: The Suppression of Domesticity in Modern Art and Architecture (London: Thames and Hudson, 1996). 